\title{
Wykorzystanie i funkcjonowanie ruin zamkowych w Iłży
}

\author{
Katarzyna Drobek \\ https://orcid.org/0000-0003-3599-1169 \\ k.drobek@pollub.pl
}

\section{Maciej Trochonowicz}

https://orcid.org/0000-0001-7742-7916

m.trochonowicz@pollub.pl

Katedra Konserwacji Zabytków, Wydział Budownictwa i Architektury, Politechnika Lubelska

\begin{abstract}
Streszczenie: Niniejszy artykuł stanowi przedstawienie obecnego funkcjonowania, zagospodarowania, stanu badań oraz stanu technicznego ruin zamkowych w Iłży. Relikty warowni są jednym z najciekawszych obiektów znajdującym się na terenie województwa mazowieckiego. Ich położenie dominujące w sylwecie miasta wykazuje duże wartości krajobrazowe całego zespołu zamkowego, który stanowi element identyfikacyjny lłży. Fortyfikacja od setek lat pozostaje w formie ruiny i jej forma jest utrwalona w pamięci i świadomości społeczeństwa. Obiekt ten obecnie jest udostępniony do ruchu turystycznego. Stale prowadzone są na nim również badania archeologiczne oraz tworzone nowe koncepcje zagospodarowania terenu zamku.
\end{abstract}

Słowa kluczowe: zamek, ruiny zamku, Iłża, zagospodarowywanie, historyczna ruina

\section{Wstęp}

Gotycko-renesansowy zamek Biskupów Krakowskich w lłży jest obiektem niezwykle ważnym i cennym dla terenu Mazowsza. Warownia powstała ok. 1340 roku z inicjatywy Jana Grota. Zamek w Iłży był zamkiem miejskim, początkowo wyłączonym z obrębu fortyfikacji miasta. ${ }^{1}$ Od początku swojego istnienia budowla ta uznawana była za jedną z lepiej ufortyfikowanych siedzib krakowskich biskupów². Była wielokrotnie przebudowywana kolejno przez biskupów Floriana z Mokrska, Jana Konarskiego, Filipa Padniewskiego i Marcina Szyszkowskiego. Już w drugiej połowie XIV w. warownia została przekształcona w celu zwiększenia jej obronności. W połowie XVI i następnie w XVII wieku uzyskała renesansowy wygląd oraz fortyfikacje bastionowe. W 1655 r. zamek został zajęty oraz zniszczony przez Szwedów, a następnie dwa lata później zdewastowany przez atak wojsk Rakoczego. Odbudowy i remonty zamku prowadzone były w połowie XVII i w XVIII wieku. Kolejnych zniszczeń dokonano w trakcie Konfederacji Barskiej. W 1789 roku, w wyniku Sejmu Czteroletniego zamek przeszedł na własność państwa.

Obiekt zaczął stopniowo niszczeć już pod koniec XVIII w. Popadł całkowicie w ruinę w wyniku pożaru na przełomie XVIII i XIX w. Na początku XX wieku zespół zamkowy stał się przedmiotem zainteresowania, ochrony, licznych badań, prac konserwatorskich i porządkowych. Niestety dotychczas nie doczekał się prac zabezpieczających o charakterze kompleksowym. Obecnie zamek Biskupów Krakowskich utrzymywany jest w formie trwałej ruiny. 


\section{Ruiny zamkowe w Iłży}

Ruiny średniowiecznego zamku Biskupów Krakowskich w lłży położone są w granicach obecnego województwa mazowieckiego, 27 km na południe od Radomia, we wschodniej części miasta - na wzniesieniu zwanym Górą Zamkową. U stóp wzgórza, od strony zachodniej znajdują się zabudowania miasta, natomiast od strony wschodniej teren łagodnie przechodzi w otaczające pola i łąki. Dolina rzeki Iłżanki oddziela skalny cypel wzgórza od miasta. Zespół zamkowy jest pod prawną opieką konserwatorską. Wpisany został do rejestru zabytków decyzją z dnia 24.03.1947 pod nr. A-23, decyzją z dnia 23.06.1967 pod nr. rej. A-156 oraz decyzją z dnia 18.03.1981 pod nr. rej. A-96. Do rejestru zabytków wpisano również park na wzgórzu zamkowym decyzją z dnia 24.03.1947 pod nr. rej. A-23.

Historycznie zamek w Iłży stanowił ufortyfikowaną siedzibę biskupów oraz pełnił funkcję centrum administracyjnego dóbr biskupich. Stacjonowało tu również wojskowo, następnie starostowie, a także miał tam swoją siedzibę sąd grodowy dla poddanych biskupów krakowskich. ${ }^{3}$ Warownia była obiektem często odwiedzanym przez królów, zatrzymał się tu m.in. Aleksander Jagiellończyk, Zygmunt Stary oraz Zygmunt III Waza. ${ }^{4}$

Obecnie pozostałości budowli obronnej są największą atrakcją miasta. ${ }^{5}$ Miejsce to posiada funkcję turystyczną, kulturalną i rekreacyjną. Dodatkowo, ze względu na swoje położenie, stanowi charakterystyczną dominantę w sylwecie miasta. Ruiny górują nad zabytkowym układem urbanistycznym Iłży (Ryc. 2), są widoczne z odległości wielu kilometrów z dróg wjazdowych i przejazdowych przez miasto. Główne otwarcia widokowe z terenu zamku uchwycono w opracowaniu studialnym z 1997 roku. $^{6}$

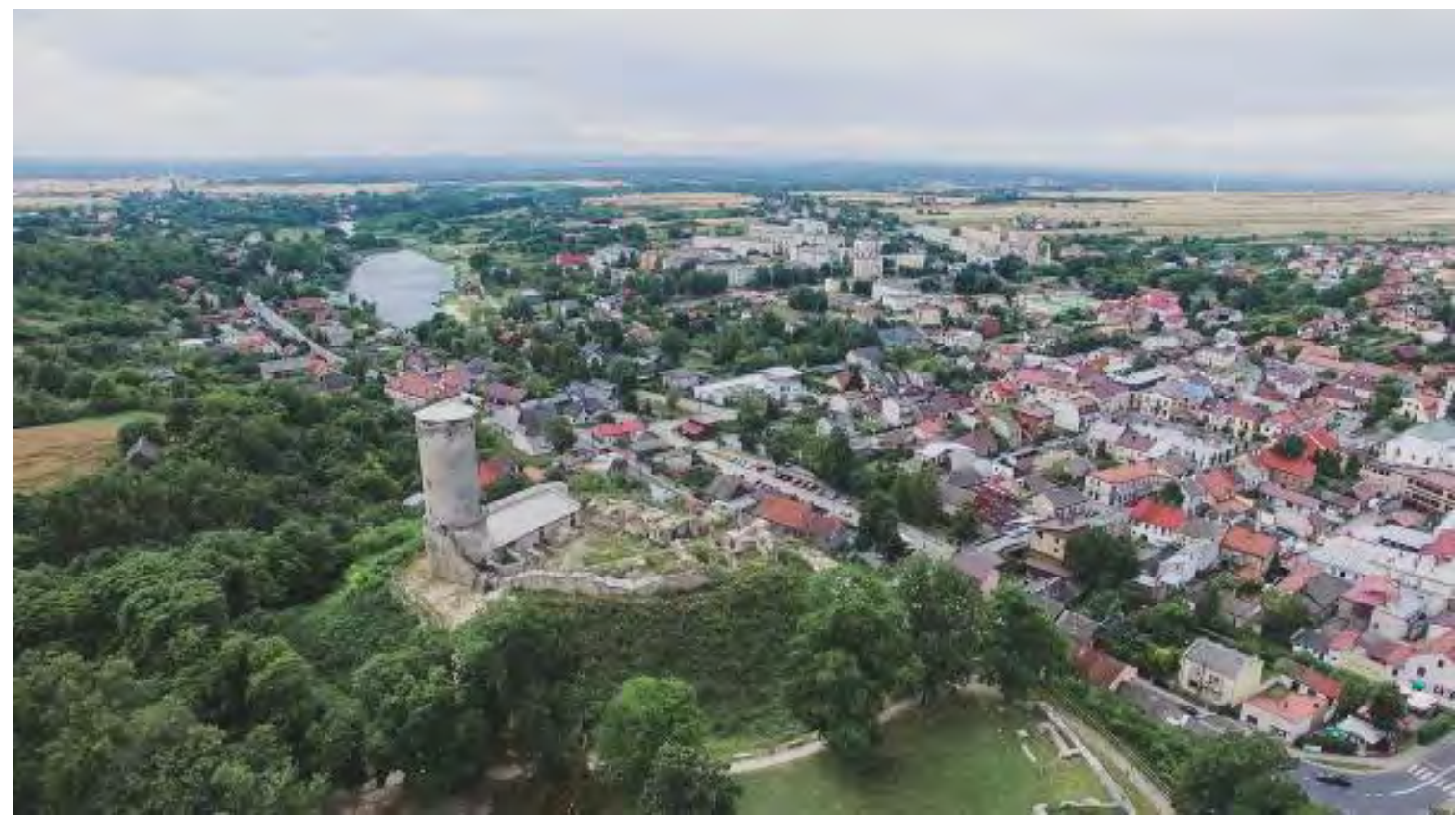

Ryc. 1. Widok na ruiny zamku oraz miasto łłża, 2018

Źródło: Archiwum Katedry Konserwacji Zabytków Politechniki Lubelskiej.

5 P. Langer, Rewitalizacja obszarów śródmiejskich w małych miastach - projekty i ich realizacja, Czasopismo Techniczne. Architektura, R. 109, z. 3-A, s. 255.

6 M. L. Lewicka, Kulturowe i społeczne wartości mazowieckich zamków w Liwie i łłży [w:] Zamki w ruinie: zasady postępowania konserwatorskiego B. Szmygin, P. Molski (red.), Lublin 2012, s. 172. 
Teren wraz z Zamkiem od 1927 roku jest w rękach Miasta i Gminy Iłża. ${ }^{7}$ Użytkownikiem baszty zamkowej jest Muzeum Regionalne w lłży. Finansowanie ruin pochodzi w głównej mierze ze środków Miasta i Gminy lłża. W 2012 r. zamek w Iłży otrzymał dotację od Urzędu Marszałkowskiego Województwa Mazowieckiego w Warszawie na wykonanie I etapu konserwacji i zabezpieczenia murów zamku górnego w Iłży. Budżet prac stanowił około 140000 złotych. W 2013 roku wykonano ze środków Regionalnego Programu Operacyjnego Województwa Mazowieckiego na lata 2007-2013 II etap konserwacji i zabezpieczeń zamku górnego. W II etapie budżet prac wyniósł około 400000 złotych. Prace towarzyszące związane z badaniami archeologicznymi, architektonicznymi i inwentaryzacyjnymi oraz utwardzenie ciągu pieszego na wzgórzu zamkowym były finansowane z budżetu Miasta i Gminy Iłża. W 2021 roku otrzymano dotację na 350000 złotych z Ministerstwa Kultury i Dziedzictwa Narodowego na prace konserwatorskie i restauratorskie oraz odtworzenie części murów. ${ }^{8}$ Dodatkowo Mazowiecki Wojewódzki Konserwator Zabytków przyznał dofinansowanie w kwocie 550000 złotych na prace konserwacyjne i odtworzeniowe części murów zamku górnego, w zakresie niezbędnym do zachowania i ustabilizowania konstrukcji. ${ }^{9} \mathrm{~W}$ ramach prac budowlanych rozpoczętych w czerwcu 2021 r., prócz zabezpieczenia murów, wykonane zostaną: odwodnienia dziedzińca oraz pomieszczeń zamku górnego, przebudowa betonowych schodów prowadzących na wieżę główną oraz tarasy widokowe w dawnych pomieszczeniach zamku. ${ }^{10}$

\section{Architektura - forma historyczna i obecna}

Na zespół zamkowy w Iłży składa się zamek górny położony na szczycie wzgórza oraz oddzielony od niego suchą fosą zamek dolny (podzamcze) znajdujący się na północy założenia. Forma architektoniczna zespołu dostosowana została do układu terenowego wzgórza, na którym powstało założenie. Zamek wybudowano z łamanego kamienia wapiennego ze wzmocnieniami na narożach z wapiennych ciosów. Powierzchnia pierwotnego założenia wynosiła ok. $1500 \mathrm{~m}^{2}$. $^{11}$

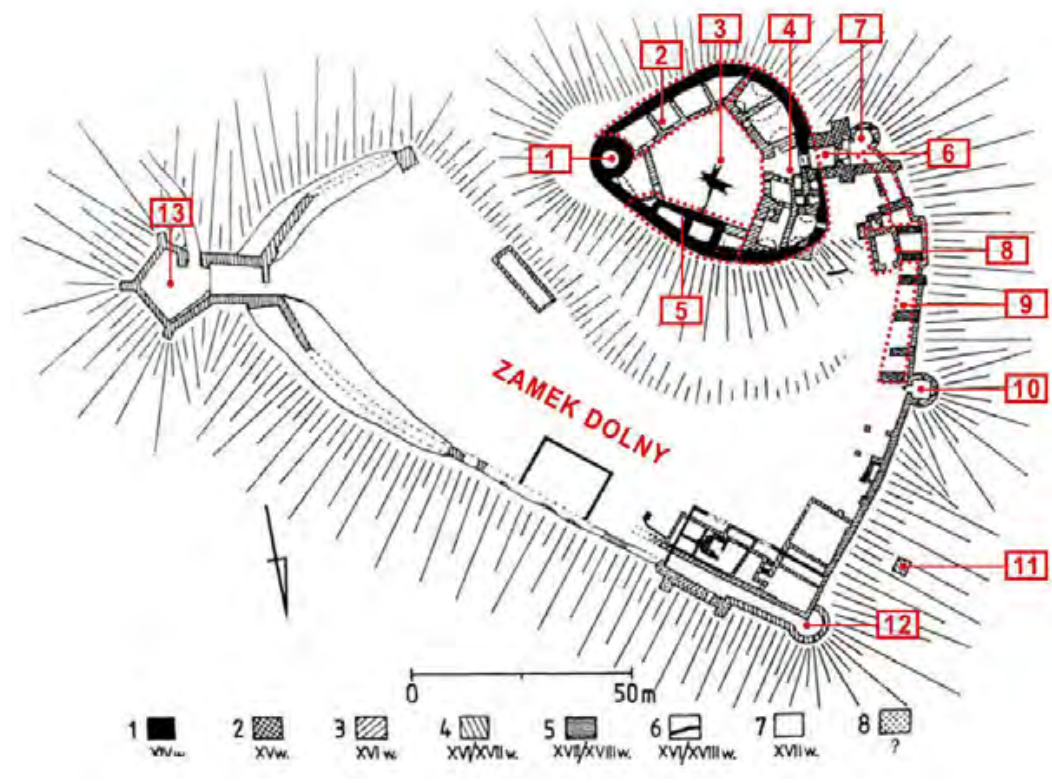

Ryc. 2. Plan zamku w Iłży

1. Wieża główna, 2. Skrzydło południowe, 3. Dziedziniec, 4. Skrzydło zachodnie, 5. Skrzydło północne, 6. Wieża bramna, 7. Baszta południowo-zachodnia, 8. Wieża przedbramna, 9. Relikty filarów mostu, 10. Baszta zachodnia, 11. Kapliczka, 12. Baszta północno-zachodnia, 13. Bastion bramny

Źródło: opracowanie własne na podstawie plan zamku wg S. Medekszy z uzupełnieniami J. Lewickiego, https://medievalheritage.eu/ pl/strona-glowna/zabytki/polska/ ilza-zamek/.

7 Archiwum Zakładowe Wojewódzkiego Urzędu Ochrony Zabytków w Warszawie Delegatura w Radomiu (AZ WUOZ DwR), sygn. 296, A. Penkalla, Właściciele wzgórza zamkowego w Iłży w XIX-XX w. Informacja archiwalna, 1993, s. 2.

8 https://www.gov.pl/web/kulturaisport/ochrona-zabytkow3 [dostęp: 12.07.2021].

9 https://bip.mwkz.pl/uploads/images/dotacje/2021/WNIOSKI_DOTACYJNE_OBJETE_DOFINANSOWANIEM_2021r.pdf [dostęp: 12.07.2021].

10 https://www.ilza.pl/aktualnosc-426-rewitalizacja_ilzeckiego_zamku_staje.html [dostęp: 12.07.2021].

11 B. Pankowski, op. cit., s. 84 . 
Zamek górny zbudowany został na planie nieregularnego owalu. Jego najstarszym oraz najbardziej charakterystycznym elementem jest okrągła wieża główna (Ryc. 2, nr 1) usytuowana w południowo-wschodniej części założenia. Wieża główna powstała prawdopodobnie w I poł. XIV w. Stanowi ona element typowy dla obiektów obronnych systemu wieżowego klasyfikowanych jako układ ośrodkowy o odmianie słupowej. ${ }^{12}$ Początkowo zwieńczona była izbicą, natomiast w II poł. XVI w. przykryto ją reprezentacyjnym hełmem. Obecnie jej wysokość wynosi ok. $25 \mathrm{~m}$, średnica korony wynosi $8 \mathrm{~m}$, natomiast grubość murów zmniejsza się ku górze, od 2,45 m do $0,8 \mathrm{~m} \cdot{ }^{13} \mathrm{~W}$ podobnym czasie co wieża, powstał dom mieszkalny w północno-zachodniej (Ryc. 2 nr 5) części warowni.

W drugiej fazie przebudowy wzmocniona została brama wjazdowa na teren zamku górnego. Poza obrębem murów powstała czworoboczna wieża bramna z przyporami w narożach (Ryc. 2, nr 6). Wieża bramna była drugim co do wysokości elementem zespołu. Do zamku prowadził most kamienny oparty na filarach (Ryc. 2, nr 9), który składał się z kilku odcinków, w tym dwóch części zwodzonych, a ostatnie przęsło mostu było podnoszone. Na drodze dojazdowej mostu usytuowano wieżę przedbramną (Ryc. 2, nr 8). ${ }^{14}$

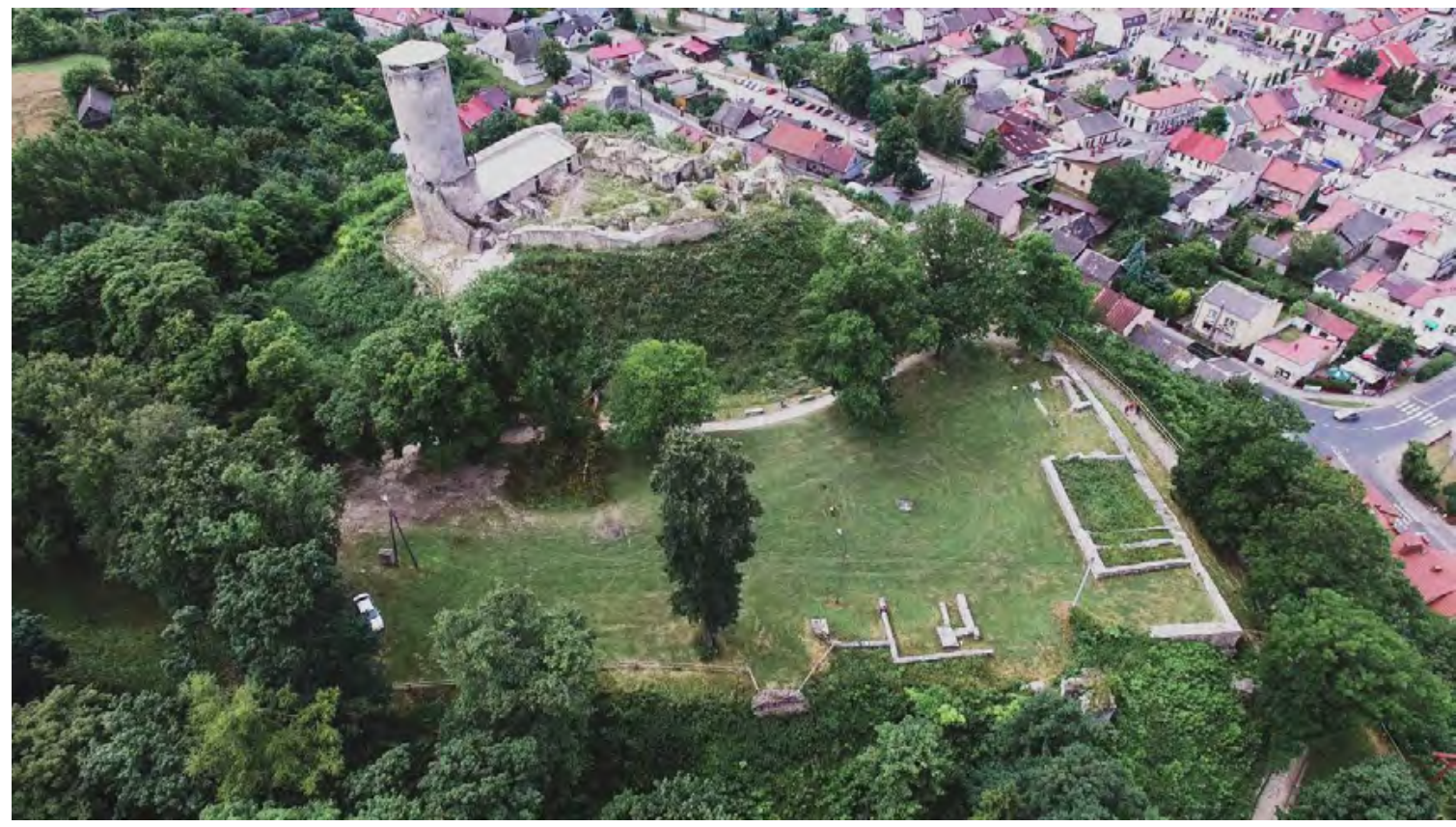

Ryc. 3. Widok na zamek górny i relikty zamku dolnego w łłży, 2018

Źródło: Archiwum Katedry Konserwacji Zabytków Politechniki Lubelskiej.

Dziedziniec (Ryc. 2, nr 3) wówczas zamknięty był od północy domem wielkim, natomiast od południa murem obwodowym. Pozostałe zabudowania gospodarcze rozlokowane były dookoła dziedzińca. W XVI wieku powstała również zabudowa przedzamcza oraz fortyfikacje bastionowe otaczające zamek niski. W tym czasie powstały również obwarowania miejskie, które połączono z zamkiem. Przy wieży bramnej znalazła się baszta południowo-zachodnia (Ryc. 2, nr 7), a wzdłuż kurtyny zachodniej powstały jeszcze dwie baszty. Zadaniem baszty południowo-zachodniej (Ryc. 2, nr 7) było wzmocnienie obrony wieży bramnej. Baszta zachodnia (Ryc. 2, nr 10) ulokowana była przy wieży przedbramnej (Ryc. 2, nr 8) i początku mostu (Ryc. 2, nr 19) prowadzącego do zamku górnego. Natomiast baszta północno-zachodnia (Ryc. 2, nr 12) kontrolowała dojazd do zamku od 
strony miasta. ${ }^{15} \mathrm{~W}$ XVII w., podczas kolejnych przebudów i umacniania warowni, powstał beluard w formie bramy wschodniej (Ryc. 2, nr 13).

Obecnie ruiny zamku stanowią czytelny obrys tzw. zamku górnego z dominantą w postaci wieży głównej (Ryc. 3). W stanie ruiny zachowany jest także mur obwodowy, zespół bramny po stronie wschodniej z wieżą przejazdową na planie czworoboku, cokoły wieży bramnej, mury zabudowy wewnętrznej przylegające do muru obwodowego (pomieszczenia na planie czworokąta w układzie jednotraktowym), dwie sklepione kolebkami piwnice na południe od dawnego wjazdu, pozostałości nowożytnej klatki schodowej przy przejeździe bramnym oraz dziedziniec zamkowy z fragmentami bruku. Na terenie podzamcza znajdują się relikty fortyfikacji bastionowych; baszty południowo-zachodniej; baszty zachodniej oraz baszty północno-zachodniej.

\section{Badania prowadzone na obiekcie oraz stan techniczny ruiny}

Ruiny zamku w Iłży są w złym stanie technicznym, wiele elementów znajduje się w stanie awaryjnym. Niska jakość oraz słaba trwałość kamienia wapiennego sprawia, że mury nieposiadające zabezpieczenia ulegają szybkiej degradacji. Proces niszczenia obiektu trwa ciągle, a wręcz jest przyspieszony ze względu na to, że niektóre elementy zamku, po wykonanych badaniach archeologicznych (szczególnie miejsca w rejonie bramy wjazdowej w skrzydle zachodnim) nie zostały zabezpieczone. Na terenie obiektu wielokrotnie prowadzone były prace badawcze, zabezpieczające oraz rekonstrukcyjne. Jednakże nigdy działania te nie miały charakteru kompleksowego. Jedynie wieża główna została całościowo objęta pracami zabezpieczającymi i zagospodarowana do celów turystycznych.

Prace na obiekcie prowadzone były od 1909 roku, kiedy to Zdzisław Lubomirski przekazał zamek wraz z otoczeniem Towarzystwu Opieki nad Zabytkami Przeszłości w Warszawie. W tym czasie powstałą pierwsza dokumentacja i inwentaryzacja pozostałości budowli obronnej. W kolejnych latach, dzięki finansom przekazanym przez Wydział Archeologii TOnZP w Warszawie przeprowadzono prace zabezpieczające zamek, które trwały aż do wybuchu I wojny światowej. Wykonano w tym czasie zabezpieczenia przy murze obwodowym i przy bramie wjazdowej na zamku górnym oraz uzupełniano ubytki w wieży głównej. W 1927 roku TOnZP odsprzedało zamek gminie Iłża i od tego czasu ruiny zaczęły funkcjonować jako obiekt turystyczny.

W latach 1962-1978 z przerwami prowadzone były badania archeologiczno-architektoniczne przy zamku w Iłży. Prowadzone były przez Zakład Historii Architektury, Sztuki i Techniki Wydziału Architektury Politechniki Wrocławskiej. Pracami badawczymi kierowali w latach 1962 Jerzy Rozpędowski i Józef Kaźmierczyk, natomiast od 1969 do 1978 r. archeolog Adam Kudła oraz architekt Stanisław Medeksza. W tym okresie rozpoznawano obiekt przy wjeździe na teren zamku oraz na jego dziedzińcu. Wynikiem działań było rozpoznanie układu przyziemia zamku. Odgruzowano także bramę wjazdową i fragment murów obwodowych oraz częściowo odkryto brukowany dziedziniec, odsłonięto nowożytny element obronny - beluard (wschodni bastion bramny). Kolejne badania odkryły przejazd przez bastion oraz bramę wschodnią. ${ }^{16}$

Na zlecenie Gminy Iłża w oparciu o zalecenia WUOZ Delegatura w Radomiu w 2009 roku miały miejsce kolejne prace archeologiczno-architektoniczne. Przed badaniami przystąpiono do odgruzowywania pomieszczeń skrzydła południowego oraz części dziedzińca. W jednym z pomieszczeń odsłonięto kamienne ocembrowanie zamkowej studni. Prace te kontynuowano w 2015 roku. Kierownikiem badań był dr Zbigniew Lechowicz, a konsultantem prof. Leszek Kajzer. Badaniami objęto wieżę bramną, pomieszczenia w skrzydle zachodnim, zagruzowane pomieszczenia skrzydła północnego oraz północną część dziedzińca. Prace miały sięgać pierwotnych poziomów użytkowych.

Powstało również kilka projektów związanych z adaptacją i zabezpieczeniem murów zamku górnego. W 1993 roku architekt Andrzej Kadłuczka wykonał projekt zagospodarowania wzgórza zamkowego, adaptacji ruin oraz ich konserwacji. ${ }^{17} \mathrm{~W} 1995$ projekt został częściowo zrealizowany - przystosowano wieżę główną do celów turystycznych. Wykonano schody prowadzące na taras widokowy na ostatnim piętrze, który zadaszono

\footnotetext{
15 P. Nowakowski, op. cit., s. 26.

16 AZ WUOZ DwR, sygn. 2015/323, Z. Lechowicz (red.), Iłża. Zamek Górny 2015 rok. Dokumentacja z odgruzowania i badań archeologicznych, 2015, s. 3.

17 AZ WUOZ DwR, sygn. 295, A. Kadłuczka, Adaptacja ruin zamku w lłży. Projekt, 1993, s. 3.
} 
lekką konstrukcją parasolową z przykryciem poliwinylowym. Kolejny projekt dotyczący konserwacji i zabezpieczenia murów zamku górnego wykonany został w 2010 roku przez architektów Jana Salm i Beatę Salm. ${ }^{18}$ Przyjęto w nim zasadę utrzymania trwałej ruiny bez prowadzenia działań rekonstrukcyjnych. Po 2012 roku, na podstawie projektu odtworzono fragment muru obwodowego na zamku górnym, a przylegające pomieszczenia pokryto dachem z gontu (modyfikacja projektu Jana Salm). ${ }^{19}$

W 2016 roku powstała koncepcja architektoniczna i funkcjonowania zamku górnego w części północnej wykonana przez dra inż. arch. Tomasza Grzelakowskiego i mgra inż. arch. Radosława Czekalskiego. Koncepcja podtrzymywała zasadę z projektu z 2010 r. dotyczącą utrzymania obiektu w formie trwałej ruiny. Projekt zakładał wykonanie żelbetowych tarasów widokowych opartych na obniżonej i wyrównanej koronie murów. ${ }^{20}$ W 2018 roku rozpoczęto jego realizację. Projekt został zatwierdzony przez Delegaturę w Radomiu MWKZ, wykonano część prac, podczas których odsłonięto poziomy użytkowe czterech pomieszczeń. W połowie roku MWKZ wstrzymało prace prowadzone na obiekcie, ponieważ stwierdzono że zatwierdzony wcześniej przez delegaturę MWKZ w Radomiu projekt stanowi zagrożenie dla zabytku. Wykonana opinia dra inż. arch. Marcina Górskiego ukazała niebezpieczeństwa wynikające z kontynuacji prac dla zamku. ${ }^{21}$

Obecnie, pomimo prowadzonych wcześniej prac konserwatorskich i zabezpieczających mury zamku górnego są w stanie technicznym niedostatecznym. Brak zabezpieczeń koron murów wykonanych z niskiej jakości materiału powoduje stałe niszczenie obiektu. W miejscach niezabezpieczonych występują różnego typu uszkodzenia konstrukcyjne i powierzchniowe. W murach występują między innymi liczne rysy, spękania, uszkodzenia lica, ubytki w spoinowaniu oraz intensywna degradacja spowodowana krystalizacją solną. W spoinach zalegają warstwy humusowe powodujące intensywny rozrost roślinności. W miejscach wykonanych wcześniej zabezpieczeń koron doszło do ich degradacji pod wpływem czynników atmosferycznych. Wykonane zabezpieczenia miały charakter czasowy i w związku z brakiem bieżących interwencji doszło do ich zużycia. ${ }^{22}$

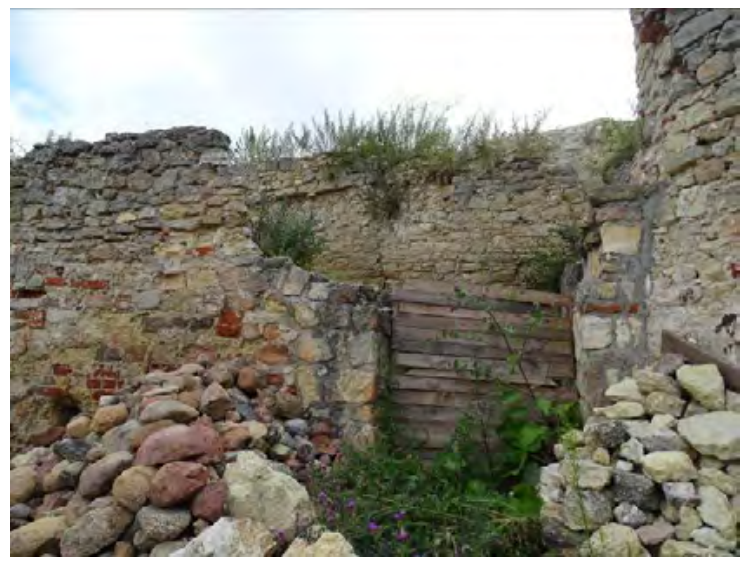

Ryc. 4. Mur w północno-wschodniej części zamku górnego widoczne liczne uszkodzenia muru oraz znaczna degradacja lica muru

Źródło: Archiwum Katedry Konserwacji Zabytków Politechniki Lubelskiej.

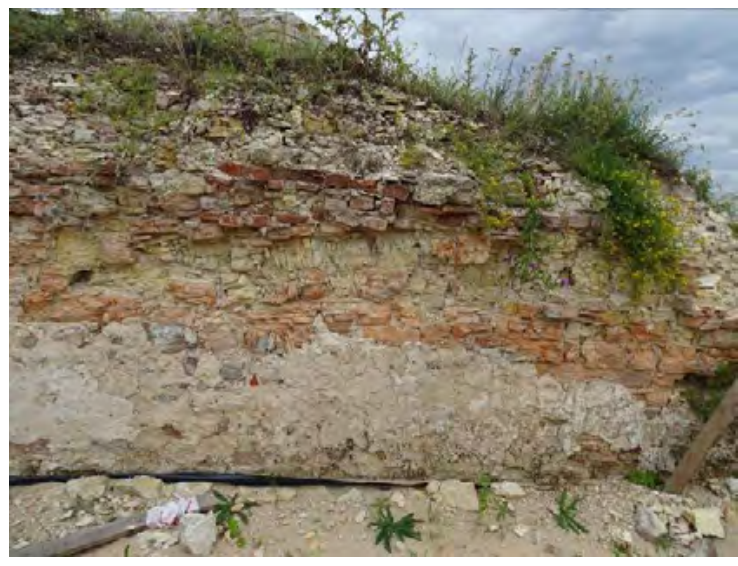

Ryc. 5. Mur wewnętrzny w zachodniej część zamku - degradacja korony murów spowodowana rozrostem roślinności. Korozja mrozowa oraz solna występująca w środkowej części muru

Źródło: Archiwum Katedry Konserwacji Zabytków Politechniki Lubelskiej.

18 AZ WUOZ DwR, sygn. 273, J. Salm, B. Salm, Projekt konserwacji i adaptacji ruin zamku górnego w Iłży woj. mazowieckie. Koncepcja, 2010.

19 J. Lewicki, Ochrona i konserwacja ruin - przemiany metod na przykładzie Mazowsza, Ochrona Dziedzictwa Kulturowego, (6), 2018, s. 119.

20 AZ WUOZ DwR, sygn. 2016/160, T. Grzelakowski, R. Czekalski, Projekt architektoniczno-budowlany wykonania robót budowlanych dotyczących zabezpieczenia pozostałości murów zamku górnego w części północnej, 2015.

21 J. Lewicki, op. cit., s. 120

22 K. Drobek, B. Szostak, B. Szmygin, M. Trochonowicz, Strategia ochrony ruin zamków woj. mazowieckiego - ocena stanu technicznego, zalecenia napraw, program ochrony - cz. II. Ocena stanu technicznego. Badania "in situ" i badania laboratoryjne, 2019. 


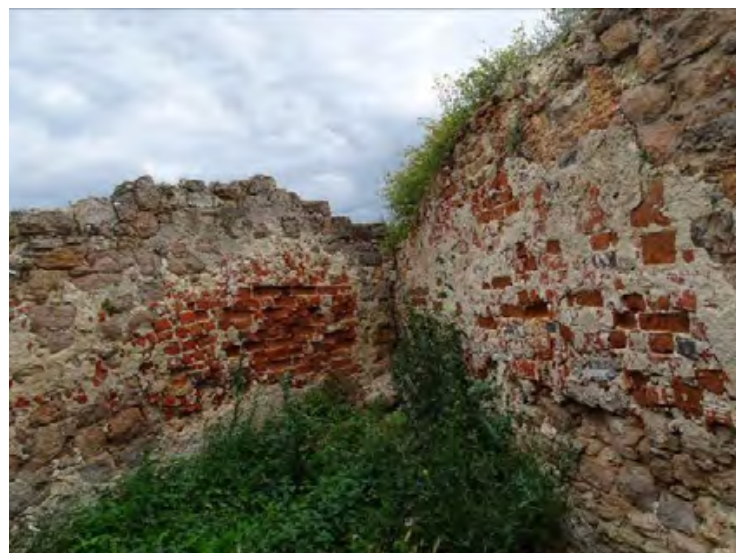

Ryc. 6. Południowo-wschodnia część zamku - intensywna korozja solna i mrozowa we fragmentach muru z cegły ceramicznej

Źródło: Archiwum Katedry Konserwacji Zabytków Politechniki Lubelskiej.

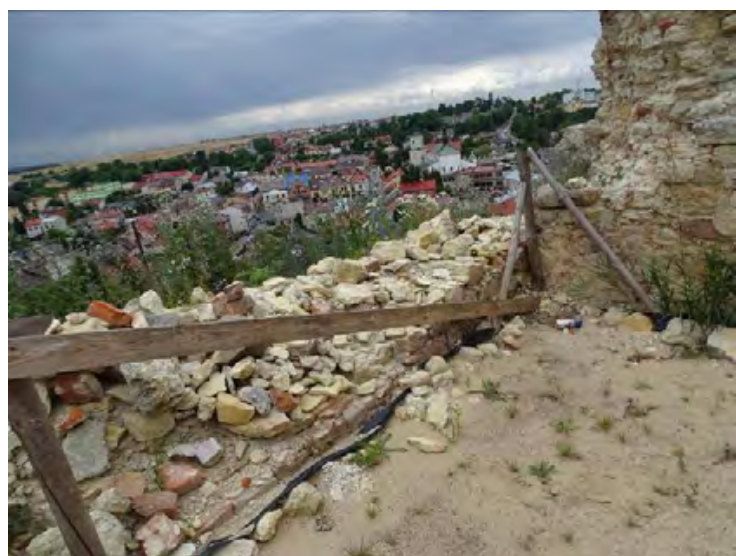

Ryc. 7. Zachodnia część zamku - całkowicie zniszczony fragment muru zewnętrznego. Miejsce niezabezpieczone po prowadzonych i nieukończonych pracach remontowych

Źródło: Archiwum Katedry Konserwacji Zabytków Politechniki Lubelskiej.

\section{Sposób użytkowania i obecne zagospodarowanie zespołu zamkowego}

Zespół zamkowy w Iłży udostępniony jest do ruchu turystycznego. Do 2020 roku dostęp na zamek górny był niekontrolowany, dlatego też nie było możliwe uzyskanie informacji dotyczących liczby odwiedzających. Do tego czasu za dopłatą dla turystów dostępna była wieża główna zarządzana przez Muzeum Regionalne w Iłży. W 2018 roku sprzedano na nią 10250 biletów $^{23}$ (dzieci do lat 7 wchodzą bez biletu). Z dużym prawdopodobieństwem, ze względu na brak biletowanego wstępu na teren zamku, ruch turystyczny był znacznie większy. Według informacji na oficjalnej stronie zamku, od sierpnia 2020 roku opłata obowiązuje również za zwiedzanie terenu dziedzińca zamku górnego. Wstęp na dziedziniec dolny w dalszym ciągu jest bezpłatny. Teren wzgórza zamkowego można zwiedzać przez cały rok, natomiast taras widokowy na baszcie dostępny jest w okresie od 1 maja do 30 września. Zamek można zwiedzać indywidualnie oraz z przewodnikiem. ${ }^{24}$

Pierwotnie dojście na wzgórze zamkowe poprowadzony było po jego zachodniej stronie. Na zamek górny dostać się można było poprzez most, biegnący niemalże równolegle do murów obronnych zamku górnego. W końcowej części skręcał ku wieży bramnej. W dwóch fragmentach most był zwodzony. Do dnia dzisiejszego zachowały się jedynie relikty bramy z przedbramiem oraz filary mostu. ${ }^{25}$

Aktualnie na wzgórze zamkowe można dostać się dwoma drogami. Pierwsze dojście rozpoczyna się od ul. Podzamcze (Ryc. 8) (naprzeciwko targowiska) i prowadzi przez betonowe schody terenowe wykonane w latach 90 XX w. na podstawie projektu z 1974 r. ${ }^{26}$ Natomiast drugie nieutwardzone dojście, o charakterze naturalnym, znajduje się od ul. świętego Franciszka, wzdłuż południowego zbocza Góry Zamkowej (Ryc. 9). Wejście na zamek górny znajduje się od strony wschodniej w miejscu dawnej sieni i kuchni, tuż przy wieży głównej. Dojście poprowadzono przez nasyp wykonany przez zasypanie części fosy (lata 1993-1995).

Na wzgórze jest także możliwość dojazdu samochodem. Droga prowadzi przez ul. świętego Franciszka (Ryc. 9) lub ul. Kampanii Wrześniowej. Parking znajduje się tuż przy południowym stoku wzgórza, dodatkowo jest możliwość parkowania w okolicznych uliczkach oraz na parkingu przy targowisku miejskim.

25 K. Drobek, B. Szostak, B. Szmygin, M. Trochonowicz, Strategia ochrony ruin zamków woj. mazowieckiego - ocena stanu technicznego, zalecenia napraw, program ochrony - cz. IV. Strategia działań, Lublin 2019.

26 AZ WUOZ DwR, sygn.. 2018/183, Z. Lechowicz, Materiały z nadzoru archeologicznego przeprowadzonego na zamku górnym w Iłży woj. mazowieckie w miesiącach maj-lipiec 2018 roku, 2018. 


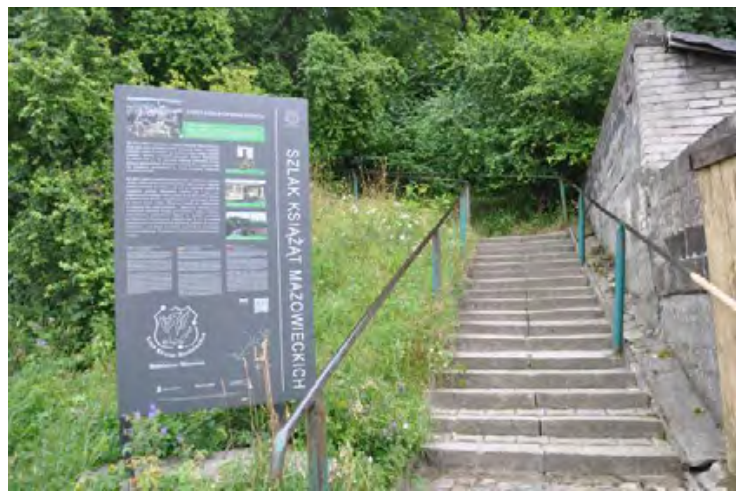

Ryc. 8. Wejście na wzgórze zamkowe od ul. Podzamcze

Źródło: Archiwum Katedry Konserwacji Zabytków Politechniki Lubelskiej.

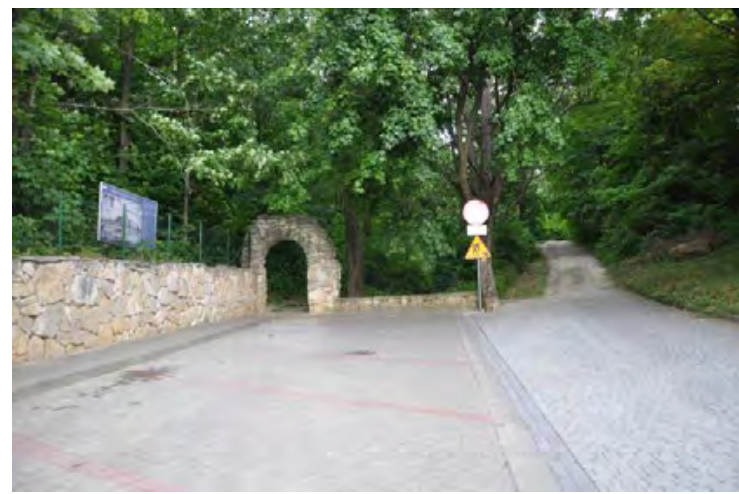

Ryc. 9. Wejście na wzgórze zamkowe od ul. świętego Franciszka

Źródło: Archiwum Katedry Konserwacji Zabytków Politechniki Lubelskiej.

Dla odwiedzających dostępny jest także sporej wielkości teren wzgórza zamkowego. Zamek górny jest w niewielkim stopniu przystosowany do ruchu turystycznego. Udostępniona jest wieża główna, na szczycie której znajduje się punkt widokowy. Dostęp do niej prowadzi początkowo przez zewnętrzne schody żelbetowe, natomiast w jej wnętrzu wykonano schody wachlarzowe wspornikowe o konstrukcji stalowej. Z tarasu widokowego wieży zamkowej oglądać można rozległe panoramy miasta oraz okolic, a widoczność sięga wielu kilometrów. W pomieszczeniach skrzydła południowego znajduje się niewielka ekspozycja związana z historią zamku.

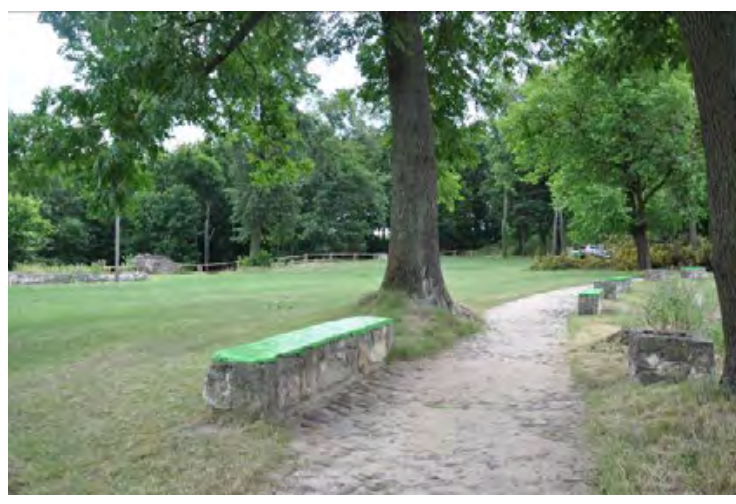

Ryc. 10. Brukowana ścieżka i elementy małej architektury na terenie wzgórza zamkowego

Źródło: Archiwum Katedry Konserwacji Zabytków Politechniki Lubelskiej.

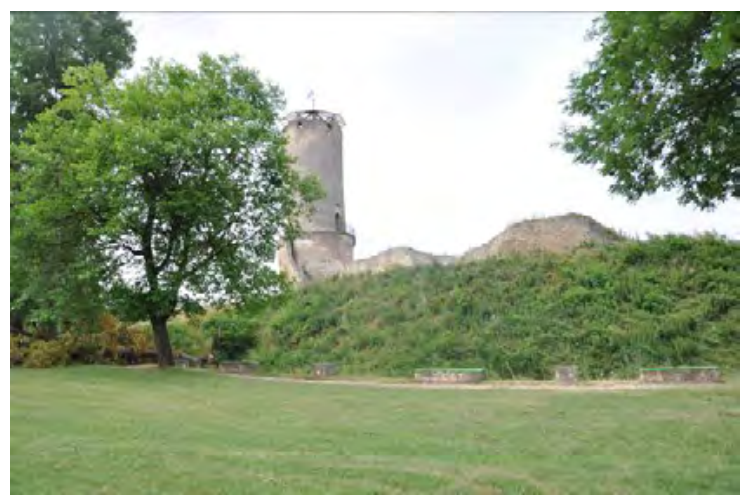

Ryc. 11. Widok z dziedzińca zamku dolnego na zamek górny Źródło: Archiwum Katedry Konserwacji Zabytków Politechniki Lubelskiej.

Rozległy dziedziniec zamku dolnego, w granicach dawnych murów, jest porośnięty roślinnością trawiastą. Na jego terenie założenia brak konkretnego zagospodarowania terenu, znajduje się tu niskiej jakości mała architektura, tj. ławki, śmietniki (Ryc. 10). Wytyczone są również ścieżki spacerowe, wykonane z bruku kamiennego. Ze względu na duże różnice wysokości, w niektórych miejscach przy wytyczonych ciągach pieszych znajdują się zabezpieczenia w formie drewnianych barierek.

Na terenie zamku dolnego oraz w wąwozie znajduje się zieleń o charakterze leśno-parkowym z kilkudziesięcioletnimi drzewami. Skarpy wzgórza zamkowego porośnięte są krzewami oraz niskimi drzewami. Zieleń ta ma charakter inwazyjny, wpływa destrukcyjnie na relikty elementów obronnych znajdujących się przy zboczach. 


\section{Podsumowanie}

Bezsprzecznie można stwierdzić, że ruiny zamku w Iłży są obiektem niezwykle ciekawym i ważnym dla województwa mazowieckiego i miasta. Niestety ich nikłe przystosowanie do ruchu turystycznego oraz przede wszystkim zły stan techniczny sprawiają, że warownia nie wykorzystuje w dostatecznym stopniu swojego potencjału. Niewielka ilość kubatur, brak konkretnych tras zwiedzania, brak zaplecza sanitarnego, brak informacji o obiekcie sprawia, że ruiny w Iłży stają się jedynie miejscem jednorazowego pobytu. Wizyty turystów są krótkie. Według informacji na oficjalnej stronie zamku, indywidualne zwiedzanie zajmuje około 45 minut. Dodatkowo oferta kulturalna obiektu jest uboga. Na terenie wzgórza zamkowego odbywa się cyklicznie jedno wydarzenie - turniej rycerski.

Zamek wraz z terenem jaki zajmuje, posiada ogromne możliwości jeżeli chodzi o jego wykorzystanie. Ruiny bezwzględnie są elementem identyfikacji miasta, częścią historycznej tożsamości oraz stanowią dominantę krajobrazową w sylwecie lłży. Niewielka ilość kubatur zamku górnego w swej obecnej formie obecnie nie pozwala na stworzenie szerszego program funkcjonalnego. Ewentualne nowe pomieszczenia powstałe w wyniku częściowej odbudowy ruin mogłyby służyć ekspozycji i zapleczu technicznemu, a przekrycie pozostałości dachem pozwoliłoby na zabezpieczenie przed dalszym niszczeniem. Ogromny teren zamku dolnego natomiast pozwala na organizację różnego rodzaju wydarzeń plenerowych o różnej skali, a także stanowić miejsce wypoczynku, rekreacji i aktywności lokalnej ludności.

Zamek biskupów krakowskich w Iłży wymaga całościowego opracowania dotyczącego zarówno kompleksowej koncepcji zabezpieczenia jak i zagospodarowania zespołu zamkowego oraz dokumentacji architektoniczno-konserwatorskiej. Opracowanie te powinny uwzględniać formę ewentualnej odbudowy wybranych elementów oraz rozwiązania techniczne służące zabezpieczeniu substancji historycznej i powstrzymaniu procesu destrukcji.

Według Mazowieckiego Wojewódzkiego Konserwatora Zabytków dra Jakuba Lewickiego istnieje również szansa na uznanie obiektu za pomnik historii. Bez wątpienia byłoby to ogromną szansą dla tego zabytku i pozwoliło na zabezpieczenie pozostałości obiektu w całości. ${ }^{27}$

\section{Bibliografia}

[1] Bogdanowski J., Architektura obronna w krajobrazie Polski: od Biskupina do Westerplatte, Warszawa-Kraków 1996.

[2] Drobek K., Szostak B., Szmygin B., Trochonowicz T., Strategia ochrony ruin zamków woj. mazowieckiego - ocena stanu technicznego, zalecenia napraw, program ochrony - cz. Il. Ocena stanu technicznego, Badania „in situ” i badania laboratoryjne, 2019.

[3] Drobek K., Szostak B., Szmygin B., Trochonowicz T., Strategia ochrony ruin zamków woj. mazowieckiego - ocena stanu technicznego, zalecenia napraw, program ochrony - cz. IV. Strategia działań, Lublin 2019.

[4] Langer P., Rewitalizacja obszarów śródmiejskich w matych miastach - projekty i ich realizacja, Czasopismo Techniczne. Architektura, R. 109, z. 3-A.

[5] Lewicki J., Rola konserwatora wojewódzkiego w ochronie i zarządzaniu Pomnikiem Historii na przykładzie Warszawy i Mazowsza, Ochrona Dziedzictwa Kulturowego (7).

[6] Lewicki J., Ochrona i konserwacja ruin - przemiany metod na przykładzie Mazowsza, Ochrona Dziedzictwa Kulturowego (6), 2018.

[7] Lewicka M.L., Kulturowe i społeczne wartości mazowieckich zamków w Liwie i lłży [w:] Zamki w ruinie: zasady postępowania konserwatorskiego, B. Szmygin, P. Molski (red.), Lublin 2012.

[8] Nowakowski P., Dzieje zamku Itża, przewodnik turystyczny, Iłża 2019.

[9] Pankowski B., Stan badań archeologicznych nad średniowiecznymi zamkami dawnego województwa sandomierskiego, Materiały i Sprawozdania Rzeszowskiego Ośrodka Archeologicznego, Tom XXX, Rzeszów 2009.

[10] Archiwum Zakładowe Wojewódzkiego Urzędu Ochrony Zabytków w Warszawie Delegatura w Radomiu (AZ WUOZ DwR), sygn. 296, Penkalla A., Właściciele wzgórza zamkowego w łłży w XIX-XX w., informacja archiwalna, 1993.

[11] AZ WUOZ DwR, sygn. 2015/323, Lechowicz Z. (red.), Iłża. Zamek Górny 2015 rok. Dokumentacja z odgruzowania i badań archeologicznych, 2015. 
[12] AZ WUOZ DwR, sygn. 295, Kadłuczka A., Adaptacja ruin zamku w Hży. Projekt, 1993.

[13] AZ WUOZ DwR, sygn. 273, Salm J., Salm B., Projekt konserwacji i adaptacji ruin zamku górnego w Iłży woj. mazowieckie. Koncepcja, 2010.

[14] AZ WUOZ DwR, sygn. 2016/160, Grzelakowski T., Czekalski R., Projekt architektoniczno-budowlany wykonania robót budowlanych dotyczących zabezpieczenia pozostałości murów zamku górnego w części północnej, 2015.

[15] AZ WUOZ DwR, sygn. 2018/183, Lechowicz Z., Materiały z nadzoru archeologicznego przeprowadzonego na zamku górnym w Iłży woj. mazowieckie w miesiącach maj-lipiec 2018 roku, 2018.

\title{
Źródła Internetowe
}

[1] https://medievalheritage.eu/pl/strona-glowna/zabytki/polska/ilza-zamek/ [dostęp: 12.07.2021].

[2] https://zamek.ilza.pl/znani-na-zamku/ [dostęp: 12.07.2021].

[3] https://www.gov.pl/web/kulturaisport/ochrona-zabytkow3 [dostęp: 12.07.2021].

[4] https://bip.mwkz.pl/uploads/images/dotacje/2021/WNIOSKI_DOTACYJNE_OBJETE_DOFINANSOWANIEM_2021r.pdf [dostęp: 12.07.2021].

[5] https://www.ilza.pl/aktualnosc-426-rewitalizacja_ilzeckiego_zamku_staje.html [dostęp: 12.07.2021].

[6] https://zamek.ilza.pl/ [dostęp: 12.07.2021].

\section{Use and functioning of the castle ruins in Iłża}

\begin{abstract}
The article presents the current functioning, development, state of research and technical condition of the castle ruins in Iłża. The relics of the fortress are one of the most interesting objects located in the Masovian Voivodeship. Their location in the city shows great landscape values of the entire castle complex, which is the identification element of Iłża. For hundreds of years, the fortification has been kept in the form of a ruin and its form is preserved in the memory and consciousness of the society. The castle is currently open to tourist traffic. Archaeological research is also carried out there and new concepts for the development of the castle area are created.
\end{abstract}

Keywords: castle, castle ruin, Iłża, development, historic ruin 